\title{
Raffia Forest Exploitation and Socio-Economic Development within Nkongsamba Urban Council
}

\author{
Gideon Samba $^{1^{*}}$ and Japhet Chianebeng Kuma ${ }^{2}$ \\ ${ }^{1}$ Department of Geography, the University of Bamenda, HTTC, Bambili-Bamenda, Cameroon. \\ ${ }^{2}$ Department of Geography and Planning, the University of Bamenda, Cameroon.
}

\begin{abstract}
Authors' contributions
This work was carried out in collaboration of both authors. Author GS designed the study, performed the statistical analysis, wrote the protocol, and wrote the first draft of the manuscript. Author JCK managed the analyses of the study and the literature searches. Both authors read and approved the final manuscript.

Article Information

DOI: $10.9734 / A J G R / 2020 / v 3 i 430118$ Editor(s):

(1) Dr. Xu Chong, Institute of Geology, China.

Reviewers:

(1) Oksana Prodius, Odessa National Polytechnic University, Ukraine.

(2) K. Sreelatha, Sreenidhi Institute of Science and Technology, India. Complete Peer review History: http://www.sdiarticle4.com/review-history/63226
\end{abstract}

Original Research Article

Received 20 September 2020

Accepted 25 November 2020

Published 15 December 2020

ABSTRACT

In Nkongsamba of the Littoral region, raffia palms exploitation have offered an impressive assortment of products for food, housing construction and households equipment to many of the community members who greatly depend on this Non-Timber Forest Products (NTFPs) for livelihood. This study examines the relationship between raffia forest exploitation and socioeconomic development within the Nkongsamba urban council in the Littoral Region of Cameroon. To achieve the main aim of the study, specific objectives were set to examine the socio-economic activities related to raffia forest exploitation in Nkongsamba, assess the relationship between raffia forest activity and socio-economic development of Nkongsamba. Data for the study were obtained through primary and secondary sources using a mixed design method of inquiry which combines both quantitative and qualitative approaches to explore data on raffia forest and its related activities in the study area. Purposive and systematic sampling techniques were equally employed for a sample population of 155 that was drawn using Miller \& Brewer Sample determination Method (2003). The data generated were analysed with descriptive and inferential statistics using Statistical Package for Social Sciences (SPSS) version 20. The major results from the analysis of the findings indicate that raffia activities have contributed enormously to socio-economic development. The 
researcher used linear regression statistics to determine if raffia forest activities have any significant impact on socio-economic development at .05 significant levels. The results showed that the calculated p-value .014 was not up to the significant level .05 placed for the study. This therefore accepts the fact that raffia forest activities have significant effect on socio-economic development. Base on this finding, the study recommended that, in view of the fact that raffia exploitation is the main economic base activity to majority of households in the area under study, the government should enact appropriate polices to promote the potentials of raffia farming households. Such households should be provided with inputs such as improved raffia harvesting materials at affordable rates.

Keywords: Raffia forest; exploitation; socioeconomic; development; Nkongsamba.

\section{INTRODUCTION}

From generation past till today, raffia palms have offered an impressive assortment of products for food and housing construction but also for fibres and fuel to mankind. In the western highlands, the grassfields and the coastal regions of Cameroon, the topography of these regions are characterized by a mosaic of different savannah types and rainforest formations, rich in useful plants among which raffia palms constitute an important non- timber forest product (NFTP) to the rural forested communities.

Works tilted toward raffia forest exploitation and Non- timber forest products especially in the African continent have received wide coverage in many research domains. Press Stott [1] asserted that the tropical rain forest is so precious to the point that it is regarded as "the lungs of the planet", given its importance as a repository of biological diversity, [2] supported Phillip's view by stating that the rain forest is regarded as a natural reservoir of genetic diversity which offers a rich source of medicinal plants, high-yield foods and a myriad of other useful products across the Sub-Saharan corridor in which Cameroon and its Ngongsamba region is included and endowed with this rich natural resource.

The increasing population of Africa, couple with rural poverty has left the rural populace with no other option than to look for means of survival towards raffia exploitation which provide them with available incomes and food which have elevated many communities from rural poverty in which the Cameroons-Nkongsamba community is one of such communities that have benefited from this rural forest products. In many communities in the African continent, one must find element of non- timber forest activities, be it forest exploitation for domestic and commercial usage, harvesting of tree fruits, and raffia for palm wine, hunting and rearing activities.
Apart from commercial purposes, raffia palms are considered as multi-functional plants par excellence used for environmental protection (conservation of water and soil); edible nuts, and cosmetic oil. The Raffia bamboo raw leaves are used for building materials, decoration, manufacture of works of art; while its elaborate sap is a delicious white wine close to palm wine $[3,4]$.

According to (Aiyeloja, Oladele \& Tumulo [5,6] about 150 NTFPs are traded nationally between countries of the African continent and the rest of the globe nowadays. In a country like Nigeria, in West Africa, non-timber forest products could be valued above timber for cultural uses including traditional medicine and food during period of scarcity. A number of Central African countries as well, including Cameroon, Congo and the Central African Republic (CAR) rely partly on forests products to satisfy their livelihood needs. Among these products, raffia provide variety of uses as palm wine, raffia fibre (Piassava broom), pulp for paper production and oils from the seeds that has prospects for industrial developments [7].

It has been noted that well above 10 million people consume palm wine in the West and central African sub-continent [8]. In almost all social-cultural ceremonies across southern Nigeria, palm wine is served as refreshment to guests during traditional weddings, births, chieftaincy coronations and funeral of elderly persons [9] cited in Falconer J. 1993 [10].

In Cameroon, raffia is considered a multipurpose plant whether it is the leaves, the fibres, the sap or the trunk, almost everything is commercialized in most regions of the country and especially in Ngongsamba where this study is carried out. Mphoweh et al. [11] opined that Cameroon is endowed with several natural resources of which 
flora covers an estimated 40,903,825 hectares of diverse ecosystems. These ecosystems produce several goods and services which are indispensable for the wellbeing of the nation like the non- timber forest products on which the population depends directly or indirectly for their socio-economic wellbeing. Among this, raffia palms constitute an important ecosystem in this flora base. They are mostly found growing in wetlands, especially around flood plains and river valleys. Their presence in several regions of Cameroon has led to its commercialization by the rural household found within the raffia-zone communities.

It is unarguable that raffia is an important nonforest product with cultural significance besides its use as medicine and food. In typical Grassfield communities in Cameroon like that of Bamunka in the flood plains of Ndop and in Santa Sub-Division as well as in the Bamelike plateau in the West region of Cameroon, the management of raffia palms portrays an important socio-economic sector seen to generate huge income to the region's inhabitants. Utensils and artefacts from raffia products are important traded products to the local households as it generate a lot of family income.

Various authors have contributed to the study of raffia in several aspects [3] examine raffia palm (Raphia taedigera) as a structural material use in housing construction in the North West region of Cameroon, [12] on his part assess raffia as vegetable resource of Tropical Africa, while [13] studied the distribution, utilization, and sustainability of raffia as non-timber Forest Products from Takamanda Forest Reserve in Cameroon. Many researches on raffia have received significant attention in Cameroon, but very little is known about the relationship between raffia forest exploitation and income generation in the forested communities especially that of Nkongsamba where raffia forest commands most socio-economic activities of the town but with very little scholarly attention. The more reason this research focus on raffia activities and it relation to income generation in communities across Nkongsamba.

\subsection{Study Area}

Nkongsamba is a town situated in the Moungo Division of the Littoral Region of Cameroon. It is located between latitude $4^{\circ} 5^{\prime} 4^{\prime \prime}$ and $5^{\circ} 10^{\prime} 00^{\prime \prime}$ North of the Equator and longitude $9^{\circ} 30^{\prime}$ and $10^{\circ} 00^{\prime}$ East of the Greenwich meridian. Nkongsamba lies at the foot of Mount Manengouba with an elevation of 828 meters above the sea level. Its population was estimated at 117,063 making it the 4th biggest town in Littoral (Nkongsamba City Council projection, 2019).

The town is situated along the Douala Bafoussam highway; N5. It is bounded to the North by Bare Bakem and Melong, to the south by Ebone, Manjo, Loum and Njombe- Penja, to the east by Nlonako Subdivision and to the west by Bangem in Kupe-Manegouba Division. The city is made up of three councils; Nkongsamba I, Nkongsamba II and Nkongsamba III with a city council headed by a government delegate. The town has an estimated population of over 130.000 inhabitants (Nkongsamba City Council population projections for 2012).

\section{METHODOLOGY}

The study adopts a quantitative and qualitative research approach to explore data on raffia forest exploitation and its contribution to socioeconomic development in Nkongsamba subdivision. The quantitative method involves the use of a survey where semi-structured questionnaires was applied to the sampled population, field observations on the various practices of raffia activities in the study area. For the purpose of in-depth analysis of the results from the quantitative analysis, a further approach called the qualitative method used included informant interviews with stakeholders such as the local households, the state authorities (Mayor and the Divisional Officer) of Nkongsamba was carried out.

The study relied on data from primary and secondary sources. Secondary data constituted text books, journals, publications, public documents, articles, dissertations, census records and a good number of internet websites related to the research topic were consulted. Primary data was collected through the administration of questionnaires to the respondents and key-informant interviews. The aim here was to facilitate the understanding of the respondents' perception on raffia exploitation and its impact on socio-economic development to the population of Nkongsamba.

The target group for the study included the inhabitants of Nkongsamba sub-division especially those involved in diverse raffia forest 
activities. This consisted of both permanent residents and stakeholders living in the study area such as raffia palm wine tappers, farmers, fishermen, business men, civil servants, tailors, craft men, and hunters. The sampled individuals consisted of persons above 18 years because this is the age one is considered matured and responsible in Cameroon as provided by the law. A base population of 117063 Inhabitants was identified. Out of this total population, 155 households were derived as target population to be sampled using [14] Miller and Brewer (2003) sample determination method at 0.08 marginal error.

The study adopted two sampling techniques. These include purposive and systematic random sampling techniques. The purposive sampling technique was used based on the subjective discretion of the researcher to select areas or elements from the population, which met the criteria established. The study area itself was chosen purposively despite the fact there existed other centres where raffia activities were practiced. The systematic sampling technique was used to sample every fifth household from the take-off point in the study area.

Data collected from the field was summarized using descriptive and inferential statistics. The descriptive statistics is presented in the form of tables, charts, frequencies, percentages, graphs, maps and photograph for clarity. The hypothesis used in the work was tested with logistic regression using Statistical Package for Social Science (SPSS), version 20. The researcher used simple linear regression to understand whether raffia forest activities have any significance effect on socio-economic development.

The equation is given as: $Y=a+b X$, where $Y$ is the dependent variable, $X$ is the independent variable (i.e. it is plotted on the $X$ axis), $b$ is the slope of the line and $a$, is the y-intercept.

\section{RESULTS AND DISCUSSION}

\subsection{Socioeconomic Activities Related to Raffia Forest Exploitation in Nkongsamba}

During fieldwork, six predominant raffia activities were identified among which are: raffia wine tapping, craftwork, medicinal plants, fruits and vegetable gathering, hunting and ceremonial decoration using raffia products. The researcher sampled the opinion of the respondents on awareness of raffia related activities as presented on Table 1. Among the 155 selected households, $99.4 \%$ respondents overwhelmingly accepted they are aware of raffia related activities in the study area. Only $0.6 \%$ respondents disagreed, this single case was considered new in Nkongsamba and does not know much about raffia exploitation in the area.

Concerning the involvement of the selected households into raffia related activities, 91.6\% accepted they do take part in raffia exploitation while $8.4 \%$ sample respondents said they are not involved in raffia forest activities.

From the various raffia activities enumerated on Table 1 , raffia wine tapping was acknowledged by $98.7 \%$ as a prominent activity in the study area $1.3 \%$ respondents refuted. Craftwork was considered as raffia related activity by $51.6 \%$ of the sample respondents, it was considered not an activity by $48.4 \%$ of the remaining sample respondents selected for the study. It was also observed that raffia forest provided good revenue through the collection of medicinal plants, among households selected for the study, $87.1 \%$ acknowledge medicinal plants as a raffia related activity and was only refused by $12.9 \%$ of the sample respondents.

The findings from the table also revealed that hunting is one of raffia forest related activity practiced in Nkongsamba, this was confirmed by $136(87.7 \%)$ of the sample respondents. This group of respondents affirmed that within raffia forest, people hunt for bush meat by setting traps arranged with raffia materials. The sample respondents who denied hunting as a raffia forest activity stood at $19,(12.3 \%)$.

The study results further confirmed fruit gathering such as raffia nuts and palm nuts as a raffia forest activity, this one was agreed to by 149 $(96.1 \%)$ of the sample respondents while the rest of the responding totalling just $6(3.9 \%)$ refused to acknowledged fruit gathering as a raffia related activity. Lastly, $148(95.5 \%)$ of the sample respondents admitted that flower decoration at ceremonious grounds such as at death, marriage and festivals uses flower products for decoration and hence this action is considered as raffia activity. On $7(4.5 \%)$ of the sample respondents refuted the opinion.

Generally, the findings of the study as presented on Table 1 above have proven without any 
doubts that all the items listed above such as wine tapping, craftwork, medicinal plants, fruit gathering, hunting and fishing are raffia forest related activities, this is confirmed from the frequency of responses from the sample individuals as presented on the Table 1 .

\subsubsection{Raffia products ranking in Nkongsamba}

A good number of products are extracted or made out of raffia forest in Nkongsamba among which is raffia wine, basket making from raffia twines, mat weaving, bamboo chairs and table, fibres for decoration of caskets and bamboo ropes and sticks.

The research finding as presented on Table 2 below sorted to know among the raffia products the most preferred, less preferred and least preferred by the sample respondents. This was done to know which of the product was in high demand in the local markets.

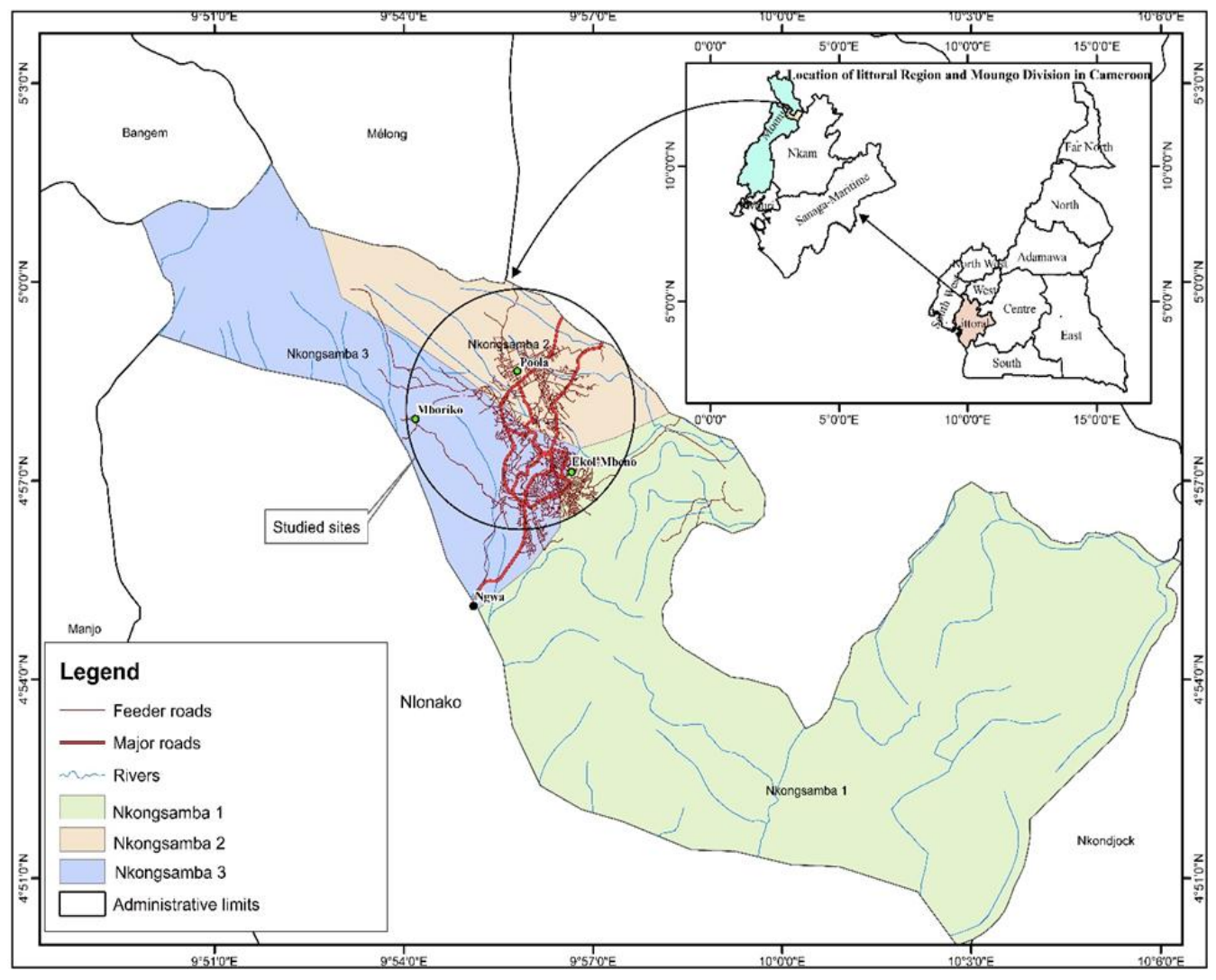

Fig. 1. Location of Nkongsamba in the littoral region Source: Authors realization from Google earth, 2020

Table 1. Raffia related activities in Nkongsamba

\begin{tabular}{llllllll}
\hline SN & Variables & Agreed & $\%$ & Disagreed & $\%$ & Valid & Total \% \\
\hline 1 & Respondents awareness & 154 & 99.4 & 1 & 0.6 & 155 & 100 \\
2 & Respondents involvement & 142 & 91.6 & 13 & 8.4 & 155 & 100 \\
\hline SN & Raffia activities & Agreed & $\%$ & Disagreed & $\%$ & Valid & Total \% \\
\hline 1 & Raffia wine tapping & 153 & 98.7 & 2 & 1.3 & 155 & 100 \\
2 & Craft work & 80 & 51.6 & 75 & 48.4 & 155 & 100 \\
3 & Search for medicinal plants & 135 & 87.1 & 20 & 12.9 & 155 & 100 \\
4 & Hunting and fishing & 136 & 87.7 & 19 & 12.3 & 155 & 100 \\
5 & Forest fruits gathering & 149 & 96.1 & 6 & 3.9 & 155 & 100 \\
6 & Decoration in ceremonies & 148 & 95.5 & 7 & 4.5 & 155 & 100 \\
\hline
\end{tabular}




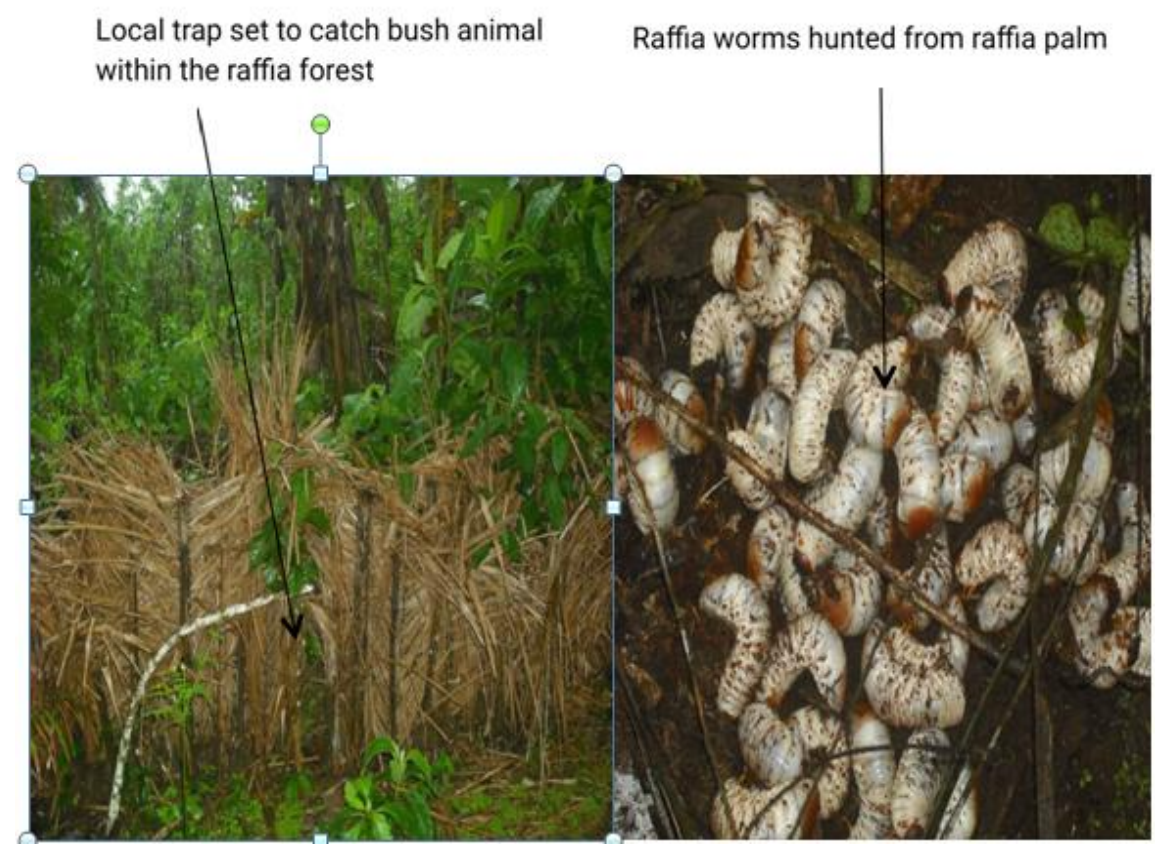

Fig. 2. Hunting of bush meat and raffia maggots in the raffia forest Source: Plates taken during fieldwork, 2020

Table 2. Raffia products ranking in Nkongsamba

\begin{tabular}{lllllllll}
\hline SN & Products from raffia & \multicolumn{7}{c}{ Product ranking } \\
\hline & & MP & $\%$ & Less P & $\%$ & Least P & $\%$ & Valid \\
\hline 1 & Raffia wine & 147 & 94.8 & 8 & 5.2 & 00 & 00 & 155 \\
2 & Basket making & 103 & 66.5 & 50 & 32.3 & 2 & 1.3 & 155 \\
3 & Mat weaving & 95 & 61.3 & 54 & 34.8 & 6 & 3.9 & 155 \\
4 & Bamboo chairs, tables & 108 & 69.7 & 32 & 20.6 & 15 & 9.7 & 155 \\
5 & Casket decoration & 81 & 52.3 & 66 & 42.6 & 8 & 5.2 & 155 \\
6 & Bamboo ropes, sticks & 104 & 67.1 & 28 & 18.1 & 23 & 14.8 & 155 \\
\hline \multicolumn{7}{c}{ Note: $M P=$ Most preferred, Less $P=$ Less Preferred, Least $P=$ Least Preferred } \\
\multicolumn{7}{c}{ Source: Author's fieldwork computation, 2020 }
\end{tabular}

Table 2 revealed that the most ranked raffia product was attributed to raffia palm wine. Responses from sample respondents shows that $147(94.8 \%)$ acknowledged raffia palm wine as the most preferred, $8(5.2 \%)$ considered it less preferred while no case was recorded for least preferred. Baskets from raffia forest was considered by $103(66.5 \%)$ of the sample respondents as most preferred, $50(32.3 \%), 50$ $(32.3 \%)$ as less preferred and $2(1.3 \%)$ as least preferred. Mat weaving was considered most preferred by 95 (61.3\%) sample respondents, it was less preferred by $54(34.8 \%)$ sample respondents while those who considered it least preferred stood at $6(3.9 \%)$. Bamboo chairs and tables made from raffia forest products was also considered as most preferable by $108(69.7 \%)$ sample respondents, it was less preferable by 32 $(20.6 \%)$ and least preferable by just $15(9.7 \%)$ sample respondents.

Casket decoration using raffia twines was considered most preferred by $81(32.3 \%)$ sample respondents, $66(42.6 \%)$ said it was a less preferred raffia product while just $8(5.2 \%)$ of the sample respondents considered it to be least preferred. Lastly, the table considered raffia ropes and sticks to be most preferred activity in Nkongsamba by $104 \quad(67.1 \%)$ sample respondents, it was considered less preferred activity by $28(18.1 \%)$ sample respondents while those who acknowledged it to be least preferred stood at $23(14.8 \%)$. Overall, judging from Table 2 as presented, the first most preferred raffia 
products according to ranking is attributed to raffia wine with 147 (94.8\%) sample respondents responses.

\subsection{Contribution of Raffia Activity to Socio-Economic Development of Nkongsamba}

Raffia activities have greatly contributed in many aspects to the development of Nkongsamba. Most areas of development identified during the field investigation included contributions through payment of school fees of children, infrastructure development like construction of community schools, roads, bridges and community town hall, the activity also serve in employment and food security.

Table 3 presents descriptive analyses of 155 sample respondents' responses on the aspects of development from raffia activities, the responses are grouped into positive and negative frequencies on a four point likert scale. The results revealed that an absolute majority of 152 $(98.1 \%)$ sample respondents overwhelmingly agreed that raffia has help in the payment of children school fees especially to those involved in the activity. It was only $4(1.9 \%)$ respondents who disagreed.

From the result findings as presented on the table, $79(50.9 \%)$ of the sample agreed that raffia activities have help in socio-economic development through infrastructure development. This group of respondent claimed that from the money gotten from sales of raffia product, they immensely contributed for the construction of community bridges, schools and roads. On the other hand, $76(49.1 \%)$ of the remaining sample respondents disagree with this aspect of infrastructural development saying that it is the work of the city council of Nkongsamba to construct roads and bridges not the citizens. The results further indicates that $94.2 \%$ sample agreed to the fact the raffia activities have contributed in improving the living standards of households especially raffia dependent households. From the sale of raffia products families are able to buy basic necessities and live up to standard. In this category, only $5.8 \%$ of the sample respondents disagreed with this point.

The table further revealed that $91.0 \%$ of the sample respondents agreed that raffia activity have contributed to development through employment of its citizens. Many households in Nkongsamba have taken up raffia activity as a profession while others have been employed in craft industries. Most of the sample respondents recommended that raffia wine have really provided employment for producers and marketers yielding substantial income to support peasant families in the rural and urban centres of Nkongsamba, this have help to reduce the rate of unemployment. Among the 155 respondents who responded to the employment situation, $9.0 \%$ refuted saying raffia activity have not solve any problem as there still exist jobless citizens in the town of Nkongsamba.

Furthermore, the table has demonstrated that food security was part of raffia initiative in the study area. Among the respondents sampled, $96.1 \%$ generally agreed that raffia activities have helped solved food problems in the study area. According to the views of this group of respondents, raffia forest in Nkongsamba offer a good number of diverse activities ranging from food and fruits gathering, hunting, fishing, palm wine, palm oil and other related activities. This makes food availability and other services abundant. The opinion of $3.9 \%$ was contrary, though this was considered minimal as they gave no justification to their responses.

The findings further confirm that raffia wine has contributed immensely in promoting social gathering especially in ceremonial places which is an aspect of cultural development. This was accepted by $85.1 \%$ of the sample respondents while $14.8 \%$ disagreed. In the domain of creation of artefact centres such as furniture workshops to make chairs, beds, and mats from raffia products, $66.5 \%$ of the sample agreed that raffia activities have promoted this sector while $33.5 \%$ of the sample disagrees.

Generally, the findings as described on Table 3 above shows that raffia activity have helped in the socio-economic development in Nkongsamba, this is proven from the study by the responses of the sample respondents with absolute majority of positive responses towards socio-economic development of the study area as a result of the presence of raffia activities.

\subsection{Estimated Monthly Income of Stakeholders from Raffia Activities}

Based on data collected on the field concerning monthly income of households derived from sales of raffia products as shown on Fig. 3 , it is worth noting that majority of the households earned between 76000-85000 FCFA per month, 
this is substantial enough to providing households needs. This estimated amount was supported by $27.7 \%$ of the sample.

It should be noted here that the estimated monthly income of the raffia producers cuts across all the strata, those who earned between 85000-100000 FCFA per month came second in the grading as shown on Fig. 3, a sample respondents of $22.6 \%$ recorded the second highest responses in this category. Those who earned between $56000-75000$ FCFA came third in the ranking with $16.8 \%$ sample. Households who earned above 100000FCFA were represented by $14.2 \%$ sample respondents and this was the fourth category of earners.

The finding also recorded those who earned between 46000-55000FCFA in fifth position. This was confirmed by $11.6 \%$ sample. Those who earned between 15000-30000FCFA was agreed by $4.5 \%$ respondents bringing this category to the sixth position. The last category of earners was attributed to those who earned between $31000-45000 F C F A$, this group of raffia producers was supported by just $2.6 \%$ of the sample respondents during the fieldwork investigation.
From general observation concerning monthly incomes of raffia producer, one can say the raffia activity generate enough money for livelihood sustenance. At least, the activity can generate enough finances to those who practice the raffia activity which can enable them spent on other requirements.

\subsection{Test of Hypothesis}

The Hypothesis stated that:

$\mathrm{H}_{0}$ : Raffia forest activities has no significant relationship with socio-economic development in Nkongsamba.

$\mathrm{H}_{1}$ : Raffia forest activities has significant relationship with socio-economic development in Nkongsamba.

The hypothesis was tested with linear regression statistics at .05 levels of significance to determine if raffia forest activities have any significant impact on socio-economic development in Nkongsamba. This was done by correlating raffia forest activities and socioeconomic development variables.

\section{Monthly income of raffia producers in FCFA}

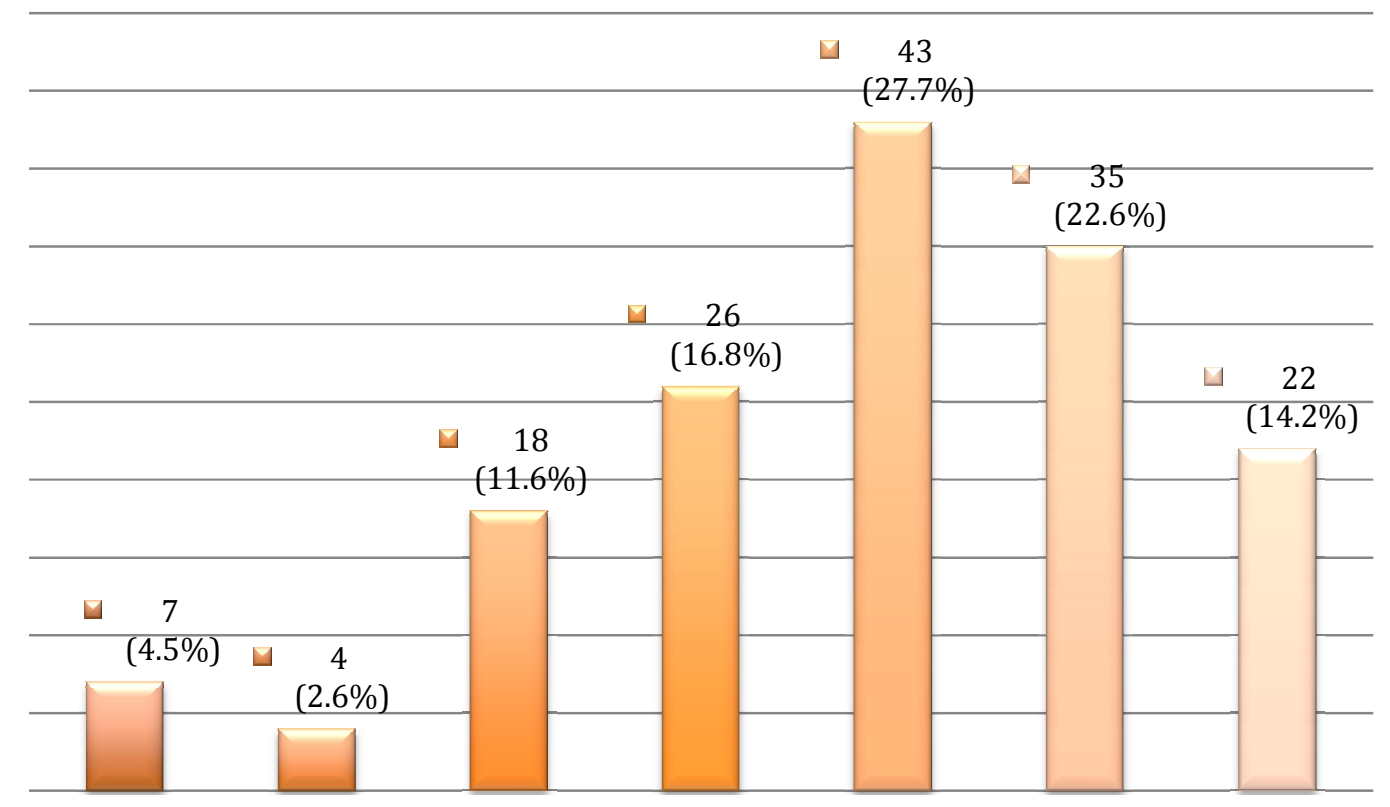

Fig. 3. Estimated monthly income of raffia producers in Nkongsamba Source: Author's fieldwork investigation 
Table 3. Contributions of raffia to socio-economic development of Nkongsamba

\begin{tabular}{|c|c|c|c|c|c|c|c|c|c|c|}
\hline \multirow{2}{*}{$\begin{array}{l}\mathrm{V} \\
\mathrm{S} / \mathrm{N}\end{array}$} & \multicolumn{4}{|c|}{ Frequency (+) } & \multicolumn{4}{|c|}{$\begin{array}{l}\text { Frequency } \\
(-)\end{array}$} & \multirow[t]{2}{*}{$\begin{array}{l}\text { Total } \\
\text { effectives }\end{array}$} & \multirow[t]{2}{*}{ Total } \\
\hline & SA & A & Total & $\%$ & D & SD & Total & $\%$ & & \\
\hline 1 & 124 & 28 & 152 & 98.1 & 1 & 3 & 4 & 1.9 & 155 & 100 \\
\hline 2 & 23 & 56 & 79 & 50.9 & 56 & 20 & 76 & 49.1 & 155 & 100 \\
\hline 3 & 90 & 56 & 146 & 94.2 & 9 & 00 & 8 & 5.8 & 155 & 100 \\
\hline 4 & 53 & 88 & 141 & 91.0 & 4 & 10 & 14 & 9.0 & 155 & 100 \\
\hline 5 & 49 & 100 & 149 & 96.1 & 00 & 6 & 6 & 3.9 & 155 & 100 \\
\hline 6 & 74 & 58 & 132 & 85.1 & 12 & 11 & 23 & 14.8 & 155 & 100 \\
\hline 7 & 50 & 53 & 103 & 66.5 & 25 & 27 & 52 & 33.5 & 155 & 100 \\
\hline
\end{tabular}

Variables used

1. Pay children school fees in school

2. Infrastructural development (roads, school)

3. Improve standard of living

4. Employment

5. Food security

6. Contribute in promoting social gathering

7. Development of artifact centers Note: $S A=S t r o n g l y$ Agreed; $A=$ Agreed; $D=$ Disagreed; $S D=$ Strongly Disagreed

Source: Author's fieldwork computation, 2020

Table 4. Linear regression test of raffia activity on socio-economic development

\begin{tabular}{|c|c|c|c|c|c|c|c|c|c|}
\hline Model & $\mathbf{R}$ & $\begin{array}{l}\text { R- } \\
\text { Square }\end{array}$ & $\begin{array}{l}\text { Adjusted } \\
\text { R-Square }\end{array}$ & $\begin{array}{l}\text { Estimat } \\
\text { ed Std. } \\
\text { Error }\end{array}$ & $\begin{array}{l}\text { Change in } \\
\text { R-square } \\
\text { change }\end{array}$ & $\begin{array}{l}\text { statistics } \\
\text { F change }\end{array}$ & Df1 & Df2 & Sig. \\
\hline 1 & $.196^{a}$ & .038 & .032 & 2.06993 & .038 & 6.120 & 1 & 153 & $.014^{*}$ \\
\hline
\end{tabular}

Source: Author's fieldwork computation, 2020

The results shows that the calculated $p$-value $.014^{*}$ was not up to the significant level .05 that was place for the study. This therefore accepts the fact that raffia forest activities have significant effect on socio-economic development. This therefore concurs with the findings that raffia activities such as selling of raffia wine, craft industries, hunting, gathering of raffia fruits and the search for medicinal plant have great effect on socio-economic development in Nkongsamba.

This hypothesis is further confirmed by the coefficient of $R$ which was calculated to be, $.196^{a}$ the $R^{2}$ was .038 and the adjusted $R^{2}$ which is a better measure of goodness of fit was calculated to be .032. Base on this result, it implies that there was a significant effect of raffia activities on socio-economic development.

\section{DISCUSSION OF FINDINGS}

The discussion of the findings was done on the basis of the fieldwork survey and the data generated through questionnaire, supported by literature review. The major findings of the study were that, raffia forest exploitation has significant effects on socio-economic development in Nkongsamba, the study also highlighted that raffia dealers make substantial income from the activity for livelihood sustainability.

The finding from the research conducted by Endamana et al. [15], investigating the contribution of non-timber forest products to cash and non-cash income of remote forest communities in Central Africa, concluded that these NTFPs contributed significantly to cash and non-cash income of households. It is a common and important source of income for the Bantu and the indigenous people living in these areas. The NTFPs account for about $55 \%$ and $45 \%$ of total cash and non-cash income for household's respondents who reported income sources from the latter. Total income values generated from the uses of each NTFP was available for the community's development such as for road construction, building of community town hall and building of community school 
especially within the study area. According to Ngalim [6], today, besides other sources of income, the harvesting of Non- Timber Forest Products (NTFPs) is not only one of the most important income generating activity for local people, but equally a source of food, medicines and serves other multipurpose values. This line of research findings has been supported by the present study on raffia exploitation and its activities has also played a significant role in supporting households income as well as in some development aspects such as raffia dependent members contributing money for construction of community bridges, schools and payment of children school fees.

After close observation and discussions with the sample population of Nkongsamba urban council on raffia exploitation and related activities that led to socio-economic development, the researcher discovered a number of lapses that the government and the urban council of Nkongsamba need to fill. The study therefore strongly recommends that: In view of the fact that raffia exploitation is the main economic base activity to majority of the households in the area under study, the government should enact appropriate polices to promote the potentials of raffia farming households. Such households should be provided with inputs such as improved raffia harvesting materials at affordable rates.

\section{CONCLUSION}

Several NTFPs have been reported to have prospects in contributing to livelihood sustainability, income generation, food security and primary health care in most sub-Saharan Central and West African communities. Raffia exploitation and related activities such as wine obtained from the sap of raffia hookier, baskets, mats, raffia chairs, ladders and drums, tables, bed and raffia twine are important NTFP produced in Nkongsamba. Raffia wine provides employment for producers and marketers yielding substantial income to support peasant families in the rural and urban centres. The study has demonstrated that Raffia forest producers and marketers operate at small scale profitably with good returns on investment in Nkongsamba. The activity have also greatly contributed to socioeconomic development through construction of community roads, bridges, payment of children schools fees, improve living standard of the raffia exploiters as well as the development of artefact centres.

\section{CONSENT}

As per international standard or university standard, participant's written consent has been collected and preserved by the author(s).

\section{COMPETING INTERESTS}

Authors have declared that no competing interests exist.

\section{REFERENCES}

1. Press Stott $P$. Dynamic forestry in an unstable world. Commonwealth Forestry Review. 1999;76 (3):207-209.

2. Panayotou T, Ashton PS. Not by timber alone: Economics and ecology for sustaining tropical forests. Washington, DC: Island; 1992.

3. Tangka JK. Raphia palm (Raphia taedigera) as structural material in the North West province of Cameroon [Master of science seminar], Department of agricultural engineering university of ibadan, Ibadan, Nigeria; 2001.

4. Elenga R, Dirras GF, Maniongui J, Biget $M$. The microstructure and physical properties of untreated Raffia textiles fibre; 2006.

Available:4010.1016/j.compositesa.2006.0 1.001

5. Aiyeloja, Oladel, Tumulo,). Potentials of Raphia hookeri Wine in Livelihood Sustenance among Rural and Urban Populations in Nigeria; 2014.

6. Ngalim, OY. Revenue components and conflicts in the use of natural resources in the peripheral zone Northeast of Korup National Park. Unpublished Master's thesis, department of forestry, the university of dschang, Cameroon. 2011;93.

7. Ohimain EI, Tuwon PE,. Ayibaebi EA. Traditional fermentation and distillation of raffia palm sap for the production of bioethanol in Bayelsa State, Nigeria. Journal of Technology Innovations in Renewable Energy. 2012;1:131-141

8. Nwachukwu IN, Ibekwe VI, Anyanwu BN. Investigation of some physic-chemistry and microbial succession parameters of palm wine. J Food Techno. 2006;4(4):308-12.

9. Okigbo BN. Plants and food in Igbo culture. Presented as the Ahiajoku Lecture, Owerri, Imo State, Nigeria; 1980.

10. Falconer J. The Major Significance of 'Minor' Forest Products: The Local Use 
and Value of Forests in the West African Humid Forest Zone. CF Note 6. (Eds) Koppell C.R.S, FAO, Rome; 1993. Available:http://www.fao.org/docrep/t9450e /t9450e00.htm

Accessed on 27th May, 2014.

11. Mphoweh JN, Tchindjan M, Mfondoum NA, Homere, The degradation of raffia palms and it's socio-economic and ecological consequences: The case study of Bamunka, Ndop, North West Province Cameroon; 2005.

12. Brink M. Raphia hookeri Mann G, Wendl H. [Internet] Record from PROTA4U. Brink, M. \& Achigan-Dako, E.G. (Editors). PROTA (Plant Resources of Tropical Africa / Ressources végétales de l'Afrique tropicale), Wageningen, Netherlands; 2002.

Available:http://www.prota4u.org/search.as p.
Accessed 27 May 2014

13. Sunderland TCH, Defo L, Ndam N, Abwe $\mathrm{M}$, Tamnjong I. A socio-economic profile of the commercial rattan trade in Cameroon. In: T.C.H.Sunderland \& J.-P. Profizi (Eds.) New Research on African Rattans. Proceedings of the International Expert Meeting on the Rattans of Africa, Limbe Botanic Gardens, Cameroon. 1-3 Feb., 2000. International Network for Bamboo and Rattans (INBAR). 2003;115-1 Available:http://www.frp.uk.com/disseminat ion_documents/INBAR_proceedings_No. 9_(2002)_English.pdf

14. Miller RL, Brewer JD. A-Z of Social Research. London: Longman; 2003.

15. Endamana et al. Contribution of non-timber forest products to cash and non-cash income of remote forest communities in Central Africa. International Forestry Review. 2016;XX(X).

(c) 2020 Samba and Kuma; This is an Open Access article distributed under the terms of the Creative Commons Attribution License (http://creativecommons.org/licenses/by/4.0), which permits unrestricted use, distribution, and reproduction in any medium, provided the original work is properly cited.

Peer-review history:

The peer review history for this paper can be accessed here: http://www.sdiarticle4.com/review-history/63226 